\title{
Rendőrképmás: sajtószabadság és képmáshoz való jog a polgári jogi és az alapjogi jogosultságok keresztútján
}

\author{
alkotmánybíráskodás - rendőrképmás - képmáshoz való jog - sajtószabadság - \\ személyiségi jogok - alkotmányjogi panasz
}

2012. január 1-jétől az Alaptörvény egy új, addig a magyar jogrendszerben nem létező jogintézményt vezetett be: az ún. valódi alkotmányjogi panaszt. Ez - az addig is létezett, konkrét normakontrollt jelentő alkotmányjogi panasszal ellentétben - nem a bírósági eljárásban alkalmazott jogszabály, hanem annak bíróság általi értelmezése alaptörvény-ellenessége esetén vehető igénybe. Ezzel az Alkotmánybíróság egy olyan hatáskört kapott, amellyel valóban a jogrendszer egészével szemben érvényesíteni tudja az alkotmányossági szempontokat, hiszen ettől az időponttól kezdve nemcsak a törvényhozó és a végrehajtó hatalom által kibocsátott jogforrásokat, hanem az egyedi bírói döntéseket is felül tudja vizsgálni, alaptörvény-ellenessé tudja nyilvánítani, és meg tudja semmisíteni. Ennél fogva az Alkotmánybíróság most már közvetlenül a jogalkalmazás felett is (alkotmányossági) kontrollt gyakorol, és akár a Kúria döntéseit is annullálhatja.

Mindez természetesen maga után vonja annak a lehetőségét, hogy a rendes bíróságok és az Alkotmánybíróság között a jogértelmezéssel kapcsolatos hatásköri viták alakuljanak ki, hiszen a törvények és az Alaptörvény alapján megállapítható értelmezés különbözőségeiből fakadóan a két szervtípus által meghozott döntések bizonyos ügytípusok vonatkozásában gyökeresen eltérő megoldásokra vezet(het)nek. A konfliktus a rendszerbe van kódolva, mivel a bíróságok a hatályos jog alapján végzik mindennapi ítélkező tevékenységüket, melynek során a jogszabályok szövege mellett a jogági dogmatikák kikristályosodott fogalmait, szabályait, elveit és értelmezési kánonjait, illetve a kialakult bírói gyakorlatot veszik figyelembe, az Alkotmánybíróság ezzel szemben - értelemszerủen - az alkotmányossági szempontokat juttatja érvényre. A bíróságoknak ugyan elvileg kötelességük az alapjogi szempontok közvetlen alkalmazása - hiszen az Alaptörvény 28. cikke kimondja, hogy „a bíróságok a jogalkalmazás során a jogszabályok szövegét elsősorban azok céljával és az Alaptörvénnyel összhangban értelmezik", mi több, az Alaptörvény tulajdonképpen ezen értelmezési kötelezettség negligálása szankciójaként tételezi az alkotmányos interpretációs kötelezettséget nem vagy helytelen módon teljesítő

* Dr. Tóth J. Zoltán egyetemi docens, Károli Gáspár Református Egyetem Állam- és Jogtudományi Kar Jogtörténeti, Jogelméleti és Egyházjogi Tanszék; főtanácsadó, Alkotmánybíróság, toth.zoltan@kre.hu. 
bíróságokkal szemben a valódi alkotmányjogi panaszt -, ám az reálisan mégsem várható a bíróságoktól, hogy maguk határozzák meg, vajon egy-egy alkalmazandó jogszabálynak mi az alkotmányos értelme.

A szükségszerü konfliktusok közül a legélesebb ellentét talán az ún. rendőrképmásos ügyek megítélése során merült fel. Ezekben az ügyekben a bíróságok sokáig következetesen a saját korábbi gyakorlatuk, az utóbbi években pedig emellett a Kúria ezen gyakorlatot cizelláló jogegységi határozata szerint ítélkeztek, az alkalmazandó Ptk.-beli rendelkezést az így kialakított dogmatikai megoldások szerint értelmezve és alkalmazva. Tették ezt még akkor is, amikor már rendelkezésükre állt az Alkotmánybíróság 28/2014. (IX. 29.) AB határozata, ${ }^{1}$ az első olyan AB határozat, amely meglehetősen egyértelmű alkotmányos szempontokat írt elő az ilyen jellegü ügyek megítélésére. Jelen elemzés azt kívánja bemutatni, hogy hogyan született a szolgálatukat teljesítő rendőrök felismerhető arcképének az érintett engedélye nélkül a sajtóban történő közzététele miatt megítélt nem vagyoni kártérítést (ma már sérelemdijat) - egyrészt a nem közérdekü ügyekre, másrészt a közérdekü ügyekben elkövetett visszaélésre, önkényességre, harmadrészt az emberi méltóság lényegi magvának sérelmére - korlátozó 28/2014. (IX. 29.) AB határozat, és hogyan próbálták annak alkalmazási körét szűkíteni a bíróságok, „megmentendő” valamit a 2014-ig fennálló korábbi gyakorlatukból. Az elemzés konklúziója, ahogy a 2014 után született alkotmánybírósági határozatoké is, hogy az alkotmányos szempontokat a bíróságok nem szükíthetik önkényesen, azoktól nem térhetnek el, és az alapjogi megítélés akkor is elsőbbséget élvez a bíróságok tételes jogi, dogmatikai és bírói gyakorlaton alapuló jogalkalmazásával szemben, ha ez utóbbit hatályos - a bíróságokra máskülönben kötelező - jogegységi határozat támasztja alá. Az alkotmányos értelmezés tehát - abban a formában, ahogyan azt az Alaptörvény autentikus értelmezésére feljogosított Alkotmánybíróság ${ }^{2}$ meghatározta - mindenkire, beleértve a bíróságokat is, kötelező. ${ }^{3}$

\section{A 28/2014. (IX. 29.) AB határozat}

A rendőrképmás sajtóbeli közzétételének lehetőségével összefüggésben megszületett alkotmánybírósági határozatok mindegyike olyan bírósági döntések Alaptörvénnyel való összhangjának kérdésében döntött, mely bírósági ítéletek különböző online tartalomszolgáltatók (internetes híroldalak) által megvalósított cselekmények vélelmezett személyiségi jogi jogsértésének ügyében születtek. $E$ bírósági döntések mindegyike ténylegesen megállapította a képmáshoz való jog sérelmét az alapul fekvő ügyekben, mégpedig a - 2013. évi V. törvény (új Ptk.) hatálybalépéséig megvalósított cselekményekre alkalmazható - 1959. évi IV. törvény (régi Ptk.) 80. $\S$-ában foglalt jogi rendelkezés értelmezésével.

$\mathrm{ABH} 813,2014$.

2 Alaptörvény 24. cikk (1) „Az Alkotmánybíróság az Alaptörvény védelmének legfőbb szerve.”

3 Az Alkotmánybíróságról szóló 2011. évi CLI. törvény (Abtv.) 39. § (1) „Ha e törvény eltérően nem rendelkezik, az Alkotmánybiróság döntése mindenkire nézve kötelező." 
A képmáshoz való jog felperes által állított sérelme esetén figyelembe veendő tágabb jogszabályi környezet releváns rendelkezései a következők. ${ }^{4}$ A régi Ptk. 75 . § (1) bekezdése értelmében a személyhez füződő jogokat mindenki köteles tiszteletben tartani, e jogok tehát abszolút szerkezetű jogviszonyok, melyek megsértését jelenti a régi Ptk. 80 . $§(1)$ bekezdése alapján a más képmásával kapcsolatos bármiféle visszaélés is. Más képmása a régi Ptk. szerint csak két esetben volt az érintett hozzájárulása nélkül nyilvánosságra hozható: egyrészt akkor, ha az nyilvános közszereplésen készült [régi Ptk. 80. § (2) bek.]; másrészt ha az eltűnt, illetve a súlyos bűncselekmény miatt büntetőeljárás alatt álló személyről készült képmás nyilvánosságra hozatala e személy felkutatásában nyújthatott segítséget, feltéve, hogy a hatóság e felhasználásra kifejezetten engedélyt adott [régi Ptk. 80. § (3) bek.]. Ezek mellett alakította ki a bírói gyakorlat az ún. tömegfelvétel fogalmát, miszerint a nem egyediesített, nem portréjellegü, személyek nagyobb csoportját ábrázoló, a felvételen látható embereket tulajdonképpen csak kulisszaként ábrázoló képek (pl. utcaképek) a felvételen szereplő személyek engedélye nélkül is nyilvánosságra hozhatók. ${ }^{5}$

A később mintaadónak bizonyult ügyben az Index.hu Zrt.-t perelte be négy rendőr. A hírportál 2011. május 6-án egy, a rendőr szakszervezetek egy része által szervezett, „Bohócforradalom” elnevezésű demonstrációról számolt be „Rendvédelmi szakszervezetek tüntetése" címmel, amelyhez mellékelt egy képgalériát is. E képek közül kettő két-két rendőrt közfeladatuk ellátása közben, a rendezvény biztosításában való közremüködésük során, egyedileg is felismerhető módon ábrázolt. Ezt a rendőrök - a korábbi bírói gyakorlat alapján - személyiségi jogaik sérelmeként értékelték, és kérték a bíróságot, hogy a jogsértés megállapítása mellett tiltsa el a hírportált a további jogsértéstől, valamint kötelezze nyilvános elégtétel adására (azaz bocsánatkérésre), illetve perköltségük megfizetésére; kártérítést azonban nem kértek. A Fővárosi Törvényszék ítéletében ${ }^{6}$ megállapította a jogsértést, így a kereseti kérelmeknek helyt adott, és kötelezte az alperest arra, hogy sajnálkozását magánlevélben fejezze ki, melyet a felperesek döntésük szerint nyilvánosságra hozhatnak.

Az ítélet indokolása szerint az egységes bírói gyakorlat értelmében a rendőrök nem közszereplők, ezért arcukat a képek közlése előtt felismerhetetlenné kellett volna tenni. A bíróság döntése alapjaként hivatkozott a régi Ptk. 75. § (1) bekezdésére, valamint a 80 . § (1) és (2) bekezdésére, amelyek szerint tehát más képmását csak meghatározott, kivételes esetekben lehetett az érintett hozzájárulása nélkül közzétenni, a konkrét esetben pedig egyik kivétel sem állt fenn. Nyilvános közszereplésröl azért nem lehetett szó, mivel a rendőrök nem saját döntésük révén vesznek részt egy demonstráció biztosításában, hanem szolgálati viszonyuk alapján, az abból fakadó kötelezettségeiket teljesítve, feletteseik utasítására (parancsára), így részvételük önkéntes jellege hiányzik, és a konkrét tüntetés biztosítása esetében is

4 A képmáshoz való személyiségi jog védelmének - jelen elemzés szempontjából nem releváns - polgári jogi aspektusairól részletesebben lásd SzEGHALmı Veronika: A képmás polgári jogi védelme és a hazai szabályozás alapvonalainak áttekintése európai példákon át. Médiakutató, 2014/1, 53-62.

5 A bírói gyakorlat szerint továbbá általában minden olyan esetben nyilvánosságra hozható a felvétel, amikor azt közérdek, avagy a készítőnek vagy a felvétel felhasználójának jogos magánérdeke szükségessé teszi.

6 Fővárosi Törvényszék 19.P.23.475/2011/4. számú ítélete, 2012. január 9. 
hiányzott. Tömegfelvételröl pedig azért nem beszélhetünk, mert mindkét képen csak a két-két, biztosítást végző rendőr volt látható. Mivel tehát a bíróság értelmezésében az utasításra eljáró rendőr pusztán attól, hogy nyilvános helyen végzi feladatát, nem minősül nyilvános közszereplőnek, ezért az Indexnek a képmásuk nyilvánosságra hozatalához a hozzájárulásukat meg kellett volna szereznie, vagy ennek hiányában képmásukat ki kellett volna takarnia.

Az alperes fellebbezett az elsőfokú döntés ellen. Arra hivatkozott, hogy a rendőrök közhatalmi tevékenységet végeznek, azaz nem magánemberként járnak el, továbbá a tömegrendezvényekröl való teljes körü, a rendöröket a rendezvénnyel kapcsolatos események bemutatásához szükséges módon, felismerhetően ábrázoló tudósítás a sajtó feladatának ellátásához nélkülözhetetlen. A Fővárosi Ítélőtábla az alperesi fellebbezéssel nem értett egyet, az elsőfokú ítéletet helybenhagyta. ${ }^{7}$ Érvelése megegyezett a Fővárosi Törvényszékével: a rendőrök azért nem közszereplök, mert tevékenységüket nem önkéntesen, hanem utasításra végzik. Közszereplőnek csak olyan személy minősül, aki a tevékenységével a társadalom jelentős számú tagját erkölcsi és/vagy anyagi értelemben jelentős mértékben befolyásolja. Az Ítélőtábla szerint a rendőrök esetében a sajtó szabad tájékoztatáshoz való joga vonatkozásában nem az egyedi személy a lényeges, hanem a feladat szakszerü elvégzése. Ez utóbbi bemutatása lehet közérdek, ahhoz azonban az egyedi rendőr felismerhető ábrázolása nem szükséges. A másodfokú bíróság szerint tehát a sajtószabadságot a szolgálatot teljesítő rendőröknek a nyilvánosságra hozott képfelvételen való, a régi Ptk. 80. § (2) bekezdésében meghatározott elöírás alapján történő felismerhetetlenné tétele nem érinti, így a fellebbezést elutasította.

Az Alkotmánybíróság azonban az ügy alkotmányossági megítélése során a sajtószabadság jogának eltérő súlyt tulajdonított. Az ítélőtáblai döntést felülvizsgáló 28/2014. (IX. 29.) AB határozatában fő szabállyá tette azt, hogy a tüntetéseket biztosító, vagy egyéb, a jelenkor eseményének minősülö rendezvényeken közremüködő, szolgálatukat végző rendőröket felismerhető módon is ábrázolni lehet, vagyis a sajtószabadság teljessége általában fontosabb, mint a közhatalom gyakorlásában részt vevő természetes személyek képmáshoz való joga. ${ }^{8}$ Ez alól egy kivételt ismert el: ha a rendör feladatteljesítés közbeni ábrázolása az emberi személyiség lényegi magját, az ember méltósághoz való jogát sérti. $A z A B$ szerint a véleménynyilvánítás szabadsága, valamint az annak részét képező sajtószabadság kiemelt alkotmányos védelmet élvező jog. ${ }^{9} \mathrm{~A}$ sajtószabadság joga garantálja a közügyekben ${ }^{10}$ történő

7 Fővárosi Ítélőtábla 2.Pf.20.656/2012/7. számú ítélete, 2013. február 7.

8 A határozathoz különvéleményt fủztek Balsai István, Dienes-Oehm Egon és Pokol Béla alkotmánybírók.

9 Vö. 30/1992. (V. 26.) AB határozat, ABH 1992, 167, 171.

10 A „közügy” fogalmának azonban nincs egzakt definíciója; ilyet sem az Alkotmánybíróság, sem a Kúria, sem semmilyen jogszabály nem adott. Annyi bizonyossággal állítható, hogy a „közügy” a politikai, illetve társadalmi kérdések eldöntésében, illetve az azt megelőző vitában való szerepvállalást takar (Navratyil Zoltán megfogalmazásában: „politikai karaktert hordoz”), így nem tekinthető közügynek a színészek, sportolók, "celebek" nyilvános szereplése, amennyiben az ilyen politikai (avagy közéleti) karakterrel nem rendelkezik. A rendőrök tüntetéseken történő részvétele (mint a közhatalom gyakorlóinak jelenléte) azért bírhat „közéleti” jelleggel, mert a közéleti kérdésekről szóló demonstrációkhoz kapcsolódik. NAVRATYIL Zoltán: Az emberi méltóság magánjogi szerepe és a véleménynyilvánítás szabadsága. In: Koltay András - Török Bernát: Sajtószabadság és médiajog a 21. század elején 3. CompLex, Budapest, 2016, 229. 
véleményalkotás és az ahhoz szükséges információszerzés, a véleménynyilvánítás, illetve a véleményformálás szabadságát, melyek nélkül a közügyekben történő tájékoztatás és az ebből következő tájékozódás lehetetlen. A sajtószabadság teljessége a közhatalom gyakorlását végző természetes személyek esetében csak akkor korlátozható, ha e személyek emberi méltósághoz való jogának lényegi magja sérül. A közhatalom gyakorlását végző személyek képmáshoz való joga korlátozható, így az ilyen személyek, például a feladatukat végző rendőrök arcképe nyilvánosságra hozható, amennyiben az a jelenkor eseményeiröl való, avagy a közhatalom gyakorlása szempontjából közérdeklődésre számot tartó tájékoztatás részeként jelenik meg, és a képmás nyilvánosságra hozatala nem visszaélésszerü, a tájékoztatás tényszerü, objektív, illetve a felvétel nem közvetít torz, bántó, sértő, lealacsonyító vagy megalázó képet a közhatalom gyakorlásában részt vevő személyröl. ${ }^{11}$ Tüntetések, demonstrációk, avagy a gyülekezési jog gyakorlását jelentő más rendezvények mindig a jelenkor eseményeinek minősülnek, így az azok biztosításában közremüködő rendőrök arcképe - ha az a fenti feltételek szerint nem visszaélésszerü - elözetes hozzájárulásuk nélkül is nyilvánosságra hozható. ${ }^{12}$

A határozat részletes indokolása szerint a rendőr, bár nem közszereplö, ${ }^{13}$ de a közhatalom gyakorlója, így a véleménynyilvánítás és a sajtó szabadsága alapján minden olyan híradás, amely egy ilyen nyilvános feladatteljesítésröl, a közhatalom gyakorlójának közügyben történő részvételéről szól, az Alaptörvény véleményszabadságot garantáló IX. cikkének kiemelt védelme alatt áll, és az azt korlátozó jogokat megszorítóan kell értelmezni. A rendőröknek és más jogállami intézmények müködtetőinek az ellenőrzése, illetve az erről a közvéleménynek szóló tudósítás ugyanis a sajtó olyan alapvető joga, amelynek elismerése és biztosítása a hatalomgyakorlás demokratikus voltának alapvető feltétele. A véleménynyilvánítási és a sajtószabadság korlátozása két indokból lehetséges. Az egyik az Alaptörvény VI. cikk (1) bekezdésében megfogalmazott, a magán- és családi élet, az otthon, a kapcsolattartás és a jó hírnév tiszteletben tartásához való jog védelme lehet. Ez azonban lényegét tekintve „titokvédelmi” szabály, és nem vonatkozik a személyek olyan tevékenységére, amelyet nem lehet a magánélet részének tekinteni - így tehát nem vonatkozik a rendőr közhatalmi tevékenységére sem, hiszen ebben az esetben hiányzik a magánszféra védelmének elemi feltétele, a „visszavonulási igény”. ${ }^{14} \mathrm{~A}$ korlátozás másik indoka a képmáshoz füződő személyiségi jog védelme lehet. Mivel azonban a képmáshoz való jog nem szerepel az Alaptörvényben, így az nem önmagában, hanem csak mint az emberi személyiség megnyilvánulása, azaz mint az emberi méltóság jogának része áll védelem alatt. ${ }^{15}$ Emiatt az olyan ábrázolás közzétételének

11 Indokolás [41].

12 Indokolás [44].

13 Az Alkotmánybíróság gyakorlatával kapcsolatos kritikaként felvethető, hogy a testület eddig egyetlen határozatában sem határozta meg, ki számít közszereplőnek. E kritikához lásd JuHÁsz Imre: Fiat libertas, pereat mundus? A véleménynyilvánítás szabadsága kontra emberi méltóság - örök küzdelem vagy békés egymás mellett élés? Alkotmánybírósági Szemle, 2016/1, 107.

14 ZAKARIÁs Kinga: Az általános személyiségi jog a Német Szövetségi Alkotmánybíróság gyakorlatában. Jogtudományi Közlöny, 2013/2, 83.

15 Indokolás [20]-[24]. 
tilalma, amely ábrázolás az ember méltóságát sérti, alkotmányosnak tekinthető, míg az olyan tilalom, ahol ilyen méltóságsérelem nem áll fenn, nem. ${ }^{16}$

A konkrét ügyben az eljáró bíróság nem állapította meg azt, hogy a kérdéses képfelvételek megalázóak, lealacsonyítóak lennének, vagy a valóságnak nem megfelelő képet közvetítenének, esetleg rossz benyomást keltenének a felvételeken szereplő személyekről. Ha a sajtószerv visszaél a sajtószabadság gyakorlásával, úgy a sajtószabadság jogára nem hivatkozhat; ennek hiányában azonban a személyiségi jogok sérelme miatt a sajtószabadság gyakorlása fő szabályként nem korlátozható. A sajtó feladata a jelenkor közéleti eseményeiröl beszámolni, így egy internetes hírportál feladata az olvasókat ezen eseményekről tájékoztatni. A sajtószerv e tájékoztatáshoz való, illetve ennek eredményeként az olvasók tájékozódáshoz füződő joga általában teljes körü kell hogy legyen. E jogok kiterjednek az adott közéleti esemény minden aspektusa nyilvánossághoz történő közvetítésére, beleértve az adott esemény biztosításában közremüködő, közhatalmat gyakorló rendőrök arcukkal történő ábrázolását is, amennyiben ez az ábrázolás a tudósítás részeként értelmezhető, nem öncélú és nem visszaélésszerú, vagyis ha az az eset körülményei alapján a jelenkor eseményeiről szóló vagy a közhatalom gyakorlása szempontjából közérdeklődésre számot tartó tájékoztatásnak, közügyet érintő képi tudósításnak minősül. Az Alkotmánybíróság megfogalmazásában: „rendőri bevetés demonstrációkon minden esetben a jelenkor eseményének minösül, [...] ezért az arról készült felvétel a képen lévők hozzájárulása nélkül közvetíthető a nyilvánosság felé, kivéve, ha ez a rendör emberi méltóságának - mint az emberi mivolt benső lényegét feltétlenül megillető védelemnek - sérelmét jelenti; ilyen lehet például a hivatása gyakorlása során megsérült rendör szenvedésének bemutatása". ${ }^{17}$ Minthogy a konkrét esetben e kivétel nem állt fenn, ezért a rendes bíróságok jogértelmezése, miszerint a régi Ptk. 80. § (2) bekezdéséből az következik, hogy a tüntetéseket biztosító rendöröknek joguk lenne arra, hogy a jelenkor eseményeivel kapcsolatos feladatuk teljesítése közben megörökített képmásukat hozzájárulásuk nélkül ne hozzák nyilvánosságra, vagyis azt a sajtószervek takarják ki, aránytalanul korlátozza a véleménynyilvánítási és a sajtószabadsághoz való jogot, ezért alaptörvény-ellenes. A nyilvános helyen készült, nem megalázó, nem lealacsonyító, tárgyilagos ábrázolást tartalmazó, azaz összességében az emberi méltóságot nem sértő képfelvétel tehát az arc felismerhetetlenné tétele nélkül, az azon szereplő közhatalmat gyakorló személy (például rendőr) hozzájárulása hiányában is nyilvánosságra hozható, amennyiben a felvétel a jelenkor eseményeihez (például egy tüntetéshez) kapcsolódik, illetve az arról szóló szabad tájékoztatás teljességéhez szükséges. ${ }^{18}$

16 Indokolás [44].

17 Indokolás [44].

18 Az Alkotmánybíróság döntése 2014. szeptember 23-án született, annak a Magyar Közlönyben történő közzétételére pedig 2014. szeptember 29-én került sor. Ekkorra azonban már megszületett a Fővárosi Ítélőtábla jogerős ítélete ellen benyújtott felülvizsgálati kérelem folytán meghozott kúriai döntés is: a Kúria 2014. január 15-i keltezésü, Pfv.IV/20.784/2013/5. számú ítéletében a felülvizsgálati kérelmet elutasította, és a jogerős ítéletet hatályában fenntartotta. A Kúria e döntésével azonos ténybeli alapokon, azonos jogi indokokkal hagyta helyben az Ítélőtábla azon ítéletét, amelyet később az Alkotmánybíróság megsemmisített. Az 
Ezt követően a Kúria végzésével ${ }^{19}$ utasította a Fővárosi Ítélőtáblát, hogy az Alkotmánybíróság határozatával megsemmisített ítélete helyett hozzon új ítéletet. $\mathrm{E}$ végzésben a Kúria előírta a Fővárosi Ítélőtábla számára, hogy az ismételt fellebbviteli eljárás során meg kell vizsgálnia a tudósítás alapjául szolgáló jelenkori esemény jellegét, a közhatalom gyakorlása megnyilvánulásának módját, a felvételek jellegét és felhasználásuk módját (a tekintetben, hogy azok megalázóak-e, öncélúak-e, torz módon ábrázolják-e a valóságot, érintik-e az ábrázolt rendőrök emberi méltóságának legbensőbb lényegét, megvalósítanak-e visszaélést vagy sem). A Kúria kimondta, hogy ha ilyen visszaélés, öncélú, megalázó, sértő stb. ábrázolás nem történt, úgy a rendőrök képmása nem takarható ki; és azt is, hogy az ezzel ellentétes jogi álláspontot elfoglaló bírói ítélet a rendőr képmáshoz való jogát a természetes személyeket általában megillető jogvédelemmel azonos szintre helyezné, amely ellentétes lenne a közhatalmat gyakorlók státusával és az ő fokozott tűrési kötelezettségükkel.

\section{Jogegységi határozat vs. alkotmánybírósági határozat: az 1/2012. BKMPJE}

Ami miatt a rendőrképmásos ügyek alkotmányjogi szempontból igazán izgalmasnak bizonyultak, az az, hogy az Alkotmánybíróság fent ismertetett határozata nem érintette a Kúria 2012. november 26-án meghozott 1/2012. Büntető közigazgatásimunkaügyi polgári jogegységi határozatát (1/2012. BKMPJE), amelyet így a bíróságoknak a régi Ptk. értelmezésekor ezen időpontot követően figyelembe kellett venniük, hiszen a jogegységi határozat a bíróságokra - a Magyar Közlönyben történő közzététel időpontjától - formálisan is kötelező. ${ }^{20} \mathrm{Az} 1 / 2012$. BKMPJE-t csak az 1/2015. Büntető közigazgatási-munkaügyi polgári jogegységi határozat (1/2015. BKMPJE) helyezte hatályon kívül 2015. február 17. napjával, így a megismételt másodfokú eljárásban az Ítélőtábla az akkor hatályban lévő 1/2012. BKMPJE alapján értelmezte a régi Ptk. 80 . $§(2)$ bekezdését.

E jogegységi határozat a rendőrök képmásának nyilvánosságra hozatala esetében megállapítandó személyiségi jogsértés kérdésében divergáló bírói gyakorlat egységessé tétele érdekében született. Ilyen ügyekben ugyanis a legtöbb bíróság a rendőrök arcának felismerhető módon történő nyilvánosságra hozatalát a régi Ptk. 80. §-ában foglalt képmáshoz való személyiségi jog megsértésének minősítette ${ }^{21}$ a Pécsi Ítélőtábla azonban egy konkrét ügyben ezzel ellentétes döntést hozott. ${ }^{22} \mathrm{~A}$ jogegységi határozat megállapította, hogy a „közszereplő” egyetlen tételes jogi fogalma, az Állambiztonsági Szolgálatok Történeti Levéltára létrehozásáról szóló 2003.

Alkotmánybíróság döntése ugyanakkor a Kúria ítéletének megsemmisítéséről nem rendelkezett, mivel az indítvány azt nem kérte.

19 A Kúria Kpkf.IV.38.031/2012/4. számú végzése.

20 A bíróságok szervezetéről és igazgatásáról szóló 2011. évi CLXI. törvény (Bszi). 42. § (1) bekezdése.

21 A Legfelsőbb Bíróság Pfv.IV.22.364/2006/4. számú ítélete nyomán.

22 BDT 2012.1. szám, a Pécsi Ítélőtábla Pfv.l.20/360/2011/6. számú ítélete. Az e döntés alapjául szolgáló tényállás azonban a többihez képest „atipikus” volt: a Pécsi Ítélőtáblának futballhuligánok ellen fellépő rendőrök felismerhető arcképei közzétételének jogszerüségéről kellett döntenie. 
évi III. törvényben meghatározott fogalom ${ }^{23}$ csak e törvény alkalmazása során irányadó. Emiatt a Ptk. „nyilvános közszereplés” fogalmát sem lehet ez alapján megítélni; azt a bírósági gyakorlatnak kell kialakítania. E korábbi gyakorlatot is figyelembe véve a jogegységi határozat szerint szereplésnek, ezen belül közszereplésnek az egyén önkéntes elhatározásán, autonóm döntésén alapuló olyan politikai, társadalmi, művészeti tevékenység, megnyilvánulás tekinthető, amelyet egy meghatározott cél, szükebb vagy tágabb értelemben a helyi közösség vagy a társadalom életének befolyásolása érdekében fejt ki. Tehát a nyilvános közszereplés a közterületen való jelenlétnél, az ott zajló eseményekben való részvételnél szűkebb kategória, feltételezi a nyilvánosság előtt fellépő, megnyilvánuló személy erre irányuló szándékát. Ebből következően a közterületen, a nyilvánosság előtt munkáját végző rendőr nem tekinthető nyilvános közszereplőnek csupán amiatt, mert a közhatalmi funkciót megtestesítő állami szerv alkalmazottja.

A hét tagból álló jogegységi tanács által meghozott 1/2012. BKMPJE-t a Kúria összes érintett szakág szerinti kollégiumai, gyakorlatilag a Kúria összes bírája, azaz a Kúria teljes ülése által meghozott 1/2015. BKMPJE helyezte hatályon kívül. ${ }^{24}$ A hatályon kívül helyezés indoka részben az Alkotmánybíróság itt elemzett döntése, illetve az abban foglalt alkotmányos szempontok korábbi bírói gyakorlattal ellentétes mivolta, részben pedig az volt, hogy az új Ptk. új szabályozást vezetett be a képmáshoz való joggal kapcsolatban. ${ }^{25}$ Ami az alkotmányossági megközelítés szempontjából fontos első indokot illeti, a Kúria az 1/2015. BKMPJE-ben megállapította, hogy az 1/2012. BKMPJE és az Alkotmánybíróság fenti határozatának indokolása között elvi ellentét nincs: a jogegységi határozat ugyanis a közszereplő fogalmának meghatározása kapcsán kimondja, hogy a rendőr nem közszereplő, illetve nem végez közszereplést; az AB határozat pedig arról rendelkezik, hogy a rendőr közhatalmat gyakorló személy, de az sem mondja ki, hogy a rendőr közszereplő lenne vagy

23 1. § (2) bekezdés 13. pont: „közszereplö: az a személy, aki közhatalmat gyakorol, gyakorolt vagy közhatalom gyakorlásával járó tisztségre jelölték, illetve aki a politikai közvéleményt feladatszerüen alakitja vagy alakította".

24 Vö. az alább tárgyalt 17/2016. (X. 20.) AB határozattal, ABH 2016, 1212, Indokolás [20]. A hatályon kívül helyezés indokait és a rendes bírósági gyakorlatra ható következményeit lásd SÁrınÉ Sımkó Ágnes: Kell-e a rendőr hozzájárulása a róla szolgálat teljesítése során készült fotó nyilvánosságra hozatalához? Új Ptk., http://ptk2013.hu/szakcikkek/kell-e-a-rendor-hozzajarulasa-a-rola-szolgalat-teljesitese-soran-keszult-fotonyilvanossagra-hozatalahoz/4789 (2017. 06. 01.).

25 Az új szabályozás három lényeges változást tartalmaz. Egyrészt fő szabály szerint már nemcsak a képmás nyilvánosságra hozatalához, hanem a fénykép bármilyen felhasználásához, valamint már eleve a képmás (fénykép, film stb.) elkészítéséhez is az érintett hozzájárulása szükséges. (Ezt egyébként ténylegesen már a régi Ptk. alapján kialakult bírói gyakorlat is elismerte, lásd BoRONKAY: i. m., 112.) Másrészt a hozzájárulás kikérése (és megadása) alóli nevesített kivételként bekerült a korábbi bírói gyakorlat által kialakított „tömegfelvétel” esetköre is. Harmadrészt az új Ptk. már nem „nyilvános közszereplésről”, hanem „nyilvános közéleti szereplésről” szól, amely az előbbihez képest szűkebb kategória, és immár bizonyosan nem foglalja magában a nyilvánosság előtt szereplő, de nem közéleti (társadalmi, politikai) kérdésekben aktív természetes személyek (színészek, műsorvezetők, sportolók, „celebek”) nyilvános szerepvállalásait. Ez a korábbi megfogalmazásból csak további, szövegen túli jogértelmezéssel volt (lett volna) levezethető. A képmáshoz való jog tartalmának az új Ptk. alapján történő ismertetését lásd PETRIK Ferenc: Polgári jog - Kommentár a gyakorlat számára (a 2013. évi V. törvény, az új Ptk. kommentárja). HVG-ORAC, Budapest, 2013, 121-122. 
közszereplést végezne. ${ }^{26}$ Ugyanakkor gyakorlati következményeiben a jogegységi határozat és az $A B$ határozat között mégiscsak ellentét feszül: előbbiből ugyanis - az egyszerü törvényi normák értelmezése alapján - az érintett rendőr hozzájárulásának hiányában a rendőri képmás sajtószerv általi kitakarásának kötelezettsége következik, utóbbiból pedig - az alapjogi szempontok figyelembevételével - nem.

\section{Rendőrképmás újratöltve: a 3/2017. (II. 25.) AB határozat}

Az 1. pontban vizsgált eljárásokat követően a Fővárosi Ítélőtábla új jogerős ítélete ${ }^{27}$ az alapeljárásban született, az Alkotmánybíróság által megsemmisített ítélettel azonos jogi következtetésekre jutott. A táblabíróság úgy látta, hogy a megismételt eljárásban is alapvetően a polgári jogi szabályok az irányadók, az alkotmányos szempontoknak pedig - az ún. közvetett hatály tana értelmében - csak az értelmezés során van jelentőségük, a magánjogi generálklauzulák alkalmazásán keresztül. Az Ítélötábla szerint az elsőfokú bíróság az alapjogi követelmények figyelembevételével együtt is helyes, a hatályos jog előírásait és az alapvető jogok érvényesülésének szempontját is megfelelően értékelő döntést hozott, mivel a rendőr önmagában azáltal, hogy tüntetésen biztosítási feladatokat lát el, nem minősül közszereplőnek, és nem végez közszereplést. Megismételte, hogy a közszereplés a bírói gyakorlat szerint a nyilvánosság igényével végzett olyan tevékenység, mellyel az érintett a társadalom jelentősebb számú tagját erkölcsi és/vagy anyagi értelemben befolyásolni képes. Ehhez hozzátartozik a nyilvános szereplés önkéntes vállalása a nyilvánosság befolyásolása érdekében; a konkrét ügyben érintett rendőrök esetében azonban sem ilyen cél, sem tevékenységük önkéntes jellege nem állt fenn.

A jogerős ítélet indokolása alkotmányjogi érvelést is tartalmazott. Ennek keretében a Fővárosi Ítélőtábla azt állapította meg, hogy a véleménynyilvánítási és a sajtószabadság, valamint a képmáshoz füződő, az emberi méltósághoz való jog részét képező személyiségi jog együttesen is érvényesülhet, akkor is, ha a rendör az arcának felismerhető bemutatását a sajtószerv részére megtagadhatja. Az Ítélőtábla hangsúlyozta, hogy az alapjogi kollízió feloldása során abból kell kiindulni, hogy a sajtószabadságról és a médiatartalmak alapvető szabályairól szóló 2010. évi CIV. törvény (Smtv.) értelmében ${ }^{28}$ a sajtószabadság gyakorlása nem járhat mások személyiségi jogainak sérelmével. A képmáshoz való személyiségi jog az önrendelkezési jog része, mivel az ember legbensőbb lényegéhez szorosan hozzátartozik, hogy saját testével, arcával maga rendelkezzék. A rendőrök pusztán ebbeli minőségükben még feladatteljesítésük során sem közszereplők, bár a közhatalom gyakorlói; személyiségi jogaik tehát - éppen a sajtó tájékoztatáshoz való jogának és a jogállami intézmények sajtó és közvélemény általi ellenőrizhetőségének érvé-

26 Az AB tehát nem állította, hogy a rendőr közszereplő lenne, és hogy ezért kellene türnie képmása nyilvánosságra hozatalát. SzEGHALmı Veronika - PAPP János Tamás: A rendőr képmásának védelme - a vita jelenlegi állása. Iustum Aequum Salutare, 2015/4, 105.

27 A Fővárosi Ítélőtábla 2.Pf.20.112/2015/4/I. számú ítélete.

${ }^{28}$ A bíróság ezen a ponton a törvény 3 . § (3) bekezdésére hivatkozott, de helyesen a 4 . § (3) bekezdésére kellett volna. 
nyesülése érdekében is - más természetes személyekhez képest korlátozottabbak, de léteznek. A rendőrök ellenőrizhetőségéhez, valamint a feladatuk ellátásáról való tájékoztatáshoz és tájékozódáshoz azonban a táblabíróság szerint nem szükséges személyükben felismerhető módon történő képi megjelenítésük. A konkrét esetben az Index.hu pusztán a rendőrök tüntetéseken való jelenlétét dokumentálta, mely anélkül is megvalósulhatott, hogy képmásukat közölte volna. A tüntetés ugyan közérdeklődésre tartott számot, azonban a másodfokú döntés szerint a rendőrök ezen demonstráción való jelenléte és dokumentált cselekvéseik nem voltak olyan jelentőségűek, amely miatt a képmáshoz füződő személyiségi joguk védelme háttérbe szorulhatott volna.

Az Index kérelme folytán lefolytatott felülvizsgálati eljárásban a Kúria hatályában fenntartotta a Fővárosi Ítélőtábla megismételt eljárásban hozott másodfokú döntését. ${ }^{29}$ Kimondta, hogy az Alkotmánybíróság megsemmisítő határozatában foglalt alkotmányossági szempontokhoz a bíróságok a megismételt eljárás során kötve vannak, ebből azonban nem következik, hogy ezen szempontok mérlegelésével ne juthatnának ugyanarra a következtetésre, mint az azok mérlegelése nélkül eredetileg meghozott döntéseikben. Megállapította, hogy a megismételt másodfokú eljárásban az Alkotmánybíróság határozatából következő mérlegelést az Ítélőtábla lefolytatta; ennek eredményeként azonban a táblabíróság újra arra a következtetésre jutott, hogy sérült a felperes rendőrök képmáshoz való joga azáltal, hogy hozzájárulásuk hiányában a hírportál a rendőrök arcképét nem takarta ki. E következtetéssel a Kúria érdemben maga is egyetértett. A Kúria szerint a kulcsmomentum az öncélúság alkotmányos értelmezése; ugyanis a rendőri intézkedésről készült képfelvétel az Alkotmánybíróság határozata értelmében akkor hozható nyilvánosságra, ha az nem öncélú, vagyis ha az vagy a jelenkor eseményeiről szóló, vagy a közhatalom gyakorlása szempontjából közérdeklődésre számot tartó, közügyeket érintő képi tudósításnak minősül. Ennek értelmezése során a Kúria azt állapította meg, hogy „a szolgálatot teljesítő rendőr képmásának hozzájárulása nélkül történő nyilvánosságra hozatala akkor marad a jelenkor történéseinek bemutatása, illetve a közhatalom gyakorlása szempontjából közérdeklődésre számot tartó tájékoztatás keretén belül, ha az az esemény hü illusztrálásához tartozik és a konkrét cselekvőség - aktív intézkedés, vagy éppen az intézkedési kötelezettség képi megjelenítésböl megállapítható nyilvánvaló elmulasztása - indokolttá teszi, ezáltal a fényképfelvétellel közölt tartalom a tudósítás tárgyát képező eseménnyel összefüggő, hírértékü információt hordoz.” Mivel a Kúria szerint „a dokumentált fényképfelvételek semmilyen többletinformációt nem nyújtanak ahhoz a köztudomású tényhez képest, hogy a rendvédelmi szakszervezetek tüntetésén - mint általában a tömegrendezvényeken, demonstrációkon - szolgálatot teljesítő rendőrök biztosították a helyszínt”, ezért „a perben kifogásolt képfelvételeknek a szolgálatot teljesítö rendőrök arcképmásával való nyilvánosságra hozatala öncélú."

29 A Kúria Pfv.IV.20.121/2016/3. számú ítélete. 
Az Alkotmánybíróság 3/2017. (II. 25.) AB határozatában ${ }^{30}$ vizsgálta a megismételt eljárásban hozott jogerős ítélet, valamint az azt hatályában fenntartó kúriai felülvizsgálati döntés alkotmányosságát. Ennek során fenntartotta azon korábbi álláspontját, hogy a rendőr mint közhatalmat gyakorló személy csak abban az esetben hivatkozhat a véleménynyilvánítási és a sajtószabadság teljes körủ érvényesülésével szemben a képmáshoz való személyiségi jogának védelmére, ha a képi közlés az emberi méltóságát, annak lényegi magvát sérti. Egyéb esetekben a sajtószabadság nem korlátozható, így a rendör a közhatalom letéteményeseként nem hivatkozhat képmáshoz való jogára, a bíróságok pedig nem nyilváníthatják a rendőrök arcát ki nem takaró képi tudósítást jogellenessé, mivel azzal a sajtószabadság teljes körủ érvényesítését legitim cél nélkül korlátoznák. ${ }^{31}$ Az Alkotmánybíróság felhívta a figyelmet arra is, hogy bár a döntésében foglalt alkotmányos szempontok konkrét esetekben való érvényesítése valóban a megismételt eljárást lefolytató rendes bíróságok feladata, ám ezen bírósági mérlegelés nem vezethet az Alkotmánybíróság által meghatározott alapjogi szempontok mellőzésére, megváltoztatására vagy szükítésére. Mivel a megismételt eljárás során az eljáró bíróságok - mind a Fővárosi Ítélőtábla, mind a Kúria - figyelmen kívül hagyták az Alkotmánybíróság által lefektetett mérlegelési szempontokat, és azok mellőzésével, lényegében az Alkotmánybíróság által meghatározott alkotmányossági követelményekkel szemben hozták meg döntéseiket, ezáltal a régi Ptk. 80 . § (2) bekezdése értelmének megállapítása és annak konkrét ügyben való alkalmazása ismét alaptörvény-ellenes eredményre vezetett. Mindezek miatt az Alkotmánybíróság a Kúria ítéletét megsemmisítette.

$A z A B$ határozat indokolása értelmében a jogerős döntés, a felülvizsgálati ítélet által is elfogadottan, azt állapította meg, hogy „a felperesek képmás védelméhez füződő személyiségi jogai sérültek az alperesi magatartás eredményeként", noha ez kifejezetten szemben ált az Alkotmánybíróság 28/2014. (IX. 29.) AB határozatában foglaltakkal. A bíróságok az öncélúság jelentését ezen Abh.-ban foglaltakhoz képest kitágították: a Fővárosi Ítélőtábla szerint ahhoz, hogy a tüntetésen szolgálatot teljesítő rendőröket ábrázoló képi tudósítás ne legyen öncélú, a rendőrök cselekvősége szükséges, a Kúria pedig még tovább ment, azt mondva ki, hogy az önkényesség hiánya csak akkor állapítható meg, ha a képi megjelenítés valamilyen hírértékủ információt hordoz. Mivel ilyen követelményt az Alkotmánybíróság a sajtószabadság érvényesüléséhez nem állított fel - ellenkezöleg, annak érvényesülését fő szabályként mondta ki, melyhez képest a sajtószabadság korlátozása (azaz a rendőrök arcának felismerhetetlenné tétele) csak a rendőrökröl készült képfelvételek visszaélésszerü bemutatása (különösen méltóságuk lényegi magjának sérelme, avagy megjelenésük megtévesztő, félrevezető bemutatása) esetén alkotmányos -, és mivel ilyen önkényesség a konkrét esetben nem merült fel, ezért megállapította a kúriai döntés alaptörvény-ellenességét.

30 ABH 2017, 190. A határozathoz párhuzamos indokolást füzött Hörcherné Marosi lldikó és Szalay Péter alkotmánybíró, továbbá különvéleményt jegyzett Czine Ágnes, Dienes-Oehm Egon és Pokol Béla alkotmánybíró.

31 Indokolás [18]. 
Általános jelleggel kimondta továbbá az Alkotmánybíróság, hogy bár a rendes bíróságok igazságszolgáltatási hatalma teljes, az nem terjed ki arra, hogy a törvények alkotmányos értelmét az Alkotmánybíróság mindenkire kötelező, ezen értelmet egyedül autentikus módon definiáló határozatában foglaltakkal ellentétesen, avagy az ott meghatározott követelmények közül szelektíven válogatva, megszorító módon állapítsák meg. ${ }^{32} \mathrm{~A}$ konkrét ügyben az Alkotmánybíróság által a 28/2014. Abh.ban meghatározott alkotmányos szempontok egyértelműek: a rendőrök arcának kitakarása, ha az a fenti értelemben nem önkényes (vagyis a rendőrök méltósághoz való jogát nem sérti, és egyébként tényszerü, nem hamis, nem félrevezető), a sajtószervektől nem követelhető meg, elmaradása pedig - a sajtószabadságnak a képmáshoz való személyiségi jog feletti primátusának érvényesülése érdekében alkotmányosan nem szankcionálható.

\section{Az AB határozatok kötelező ereje és a bíróságok „mozgástere”: a további két rendőrképmásos ügy tapasztalatai}

Az Alkotmánybíróság rendőrképmásos ügyekkel kapcsolatos gyakorlatából nemcsak a képmáshoz való jog terjedelmének alkotmányos szempontjaira nézve vonhatunk le következtetéseket, hanem általában a bíróságok és az Alkotmánybíróság kapcsolatának jellegére nézve is. Az alábbiakban elemzett két újabb, a 28/2014. (IX. 29.) $A B$ határozat meghozatala után kibocsátott rendes bírósági döntések Alaptörvénnyel való összhangját elbíráló határozatban az Alkotmánybíróság végeredményben azt az üzenetet fogalmazta meg a bíróságok számára, hogy az általa a korábbi határozataiban lefektetett alkotmányos szempontokat a konkrét ügyekben döntő rendes bíróságoknak kell ugyan érvényesíteniük, ám ennek során kötve vannak a jogszabályok Alkotmánybíróság által meghatározott alkotmányos értelméhez. Ezen értelmezés alkalmazását tehát sem akkor nem mellőzhetik, ha az azt megfogalmazó $A B$ határozat meghozatalára a bírósági eljárásra okot adó történeti tényállás megvalósulása idején még nem került sor, sem akkor nem térhetnek el töle, ha a Kúria által meghozott hatályos jogegységi határozat annak ellentmond. E kritériumok egyértelmúvé tételére két, egyazon napon meghozott $A B$ határozatban került sor: a 16/2016. (X. 20.) és a 17/2016. (X. 20.) AB határozatban.

A 16/2016. (X. 20.) AB határozat ${ }^{33}$ alapjául szolgáló ügyben a készenléti rendőrség egy tagja 2014-ben amiatt indított polgári peres eljárást az ATV Zrt. ellen, mert az a honlapján egy olyan, nem általa készített amatőr videofelvételt tett közzé, melyen a rendőr hosszan, jól felismerhetően látható, miközben egy jogszerü kilakoltatás biztosításában müködik közre. E felvétel a tévétársaság honlapján tíz hónapon keresztül megtekinthető volt. A felperes rendört, aki egy Heves megyei faluban lakott, és másodállásban egy gázcseretelepet üzemeltetett, falubeli ismerősei részéről e cselekmény tudomásukra jutását követöen számos sérelem érte, a nép sanyargatójának nevezték őt, fenyegető megjegyzéseket kapott, és többen emiatt nem hozzá,

32 Indokolás [27].

${ }^{33}$ ABH 2016, 1204. A határozathoz Dienes-Oehm Egon és Pokol Béla alkotmánybírák különvéleményt csatoltak. 
hanem egy másik gázcseretelepre mentek gázpalackért. Mindezek okán $300000 \mathrm{Ft}$ nem vagyoni kártérítést kért a tévétársaságtól, amelyet a képmáshoz való személyiségi jogának megsértése miatt a Pesti Központi Kerületi Bíróság (PKKB) meg is ítélt neki. ${ }^{34}$

A PKKB rögzítette, hogy a rendör nem közszereplö. Ennek kapcsán az akkor hatályban lévő 1/2012. BKMPJE fogalommeghatározását vette figyelembe, amely a régi Ptk. 80. $\S(2)$ bekezdését értelmezve azt mondta ki, hogy „a nyilvános helyen vagy közterületen szolgálati kötelezettséget teljesítő vagy munkát végző személy e tevékenységének ellátása során nem minősül közszereplönek, ezért a személyt beazonositható módon, egyediesitetten ábrázoló képmás vagy hangfelvétel nyilvánosságra hozatalához szükséges a hozzájárulása". A bíróság kifejtette, hogy az itélete meghozatalakor már ismert 28/2014. Abh. rá nézve nem kötelező, egyrészt azért, mert egyedi ügyben született, másrészt azért, mert az az ügy alapjául szolgáló történeti tényállás (az amatőr videofelvétel honlapon történő megjelenítése) után lett csak közzétéve, harmadrészt pedig az egyébként sem ronthatja le a bíróságra kötelező 1/2012. BKMPJE-t, amely viszont a történeti tényállás megvalósulásakor már hatályos volt.

Ettől függetlenül a bíróság végzett alapjogi mérlegelést, de annak eredményeként arra jutott, hogy a 28/2014. Abh.-ban foglalt szempontok jelen ügyben nem alkalmazhatók. Az elsőfokú bíróság szerint a közhatalom gyakorlása szempontjából közérdeklődésre számot tartó ügynek - a 28/2014. Abh. bíróság általi értelmezése alapján - csak a tüntetések, demonstrációk minősülnek, és a rendőrök szereplése ezen események alkalmával is csak abban az esetben tart számot közérdeklődésre, ha a rendőrök nyilvánvaló eljárási szabálysértést követnek el; a „jelenkor eseménye” pedig csak olyan esemény lehet, amely kifejezetten a jelenkorra jellemzö, vagyis amely a múltban szokásosan nem fordult elö. Mivel a konkrét ügyben a bíróság megállapítása szerint a rendőrök nem demonstráción teljesítettek szolgálatot, és a rájuk vonatkozó szabályokat sem szegték meg, valamint „a filmen látható kilakoltatás a jelenkorra jellemző eseménynek sem nevezhető, a végrehajtás, az állami kényszer alkalmazása ugyanis az államszervezettel egyidős", ezért a 28/2014. Abh.-ban foglalt követelmények egyike sem valósult meg, így az ott meghatározott alkotmányos szempontok alkalmazásának relevanciája sem vetődhetett fel. Ezért a bíróság az ítéletét az 1/2012. BKMPJE-re alapozta, megállapította az ATV jogsértését, és megítélte a felperesnek a kért nem vagyoni kártérítést.

Az alperes médiaszolgáltató által benyújtott fellebbezés folytán másodfokon eljárt Fővárosi Törvényszék a PKKB ítéletét helybenhagyta. ${ }^{35}$ Bár a döntés meghozatalakor a Kúria az 1/2012. BKMPJE-t az 1/2015. BKMPJE-vel már hatályon kívül helyezte, a másodfokú bíróság úgy látta, hogy a tényállás megvalósulásakor az még hatályos volt, így neki is ez alapján kell a döntését meghoznia; folyamatban levő ügyekben továbbá sem az eset után közzétett 28/2014. Abh., sem az 1/2015. BKMPJE nem alkalmazható. A mindezek folytán egyedül releváns hatályos jogforrás, az 1/2012. BKMPJE alapján a Törvényszék az elsőfokú bírósággal egyező jogi

\footnotetext{
34 A Pesti Központi Kerületi Bíróság 36.P.90.562/2014/6. számú ítélete, 2015. január 20.

35 A Fővárosi Törvényszék 56.Pf.632.194/2015/3. számú ítélete, 2015. június 9.
} 
következtetésre jutott, és az ATV fellebbezését elutasította, egyetértve mind az elsőfokú bíróság által megállapított tényállással, mind annak jogi érveivel, köztük az alkotmányjogi érvekkel is.

Az Alkotmánybíróság azonban a 16/2016. (X. 20.) AB határozatával a Fővárosi Törvényszék jogerös ítéletét alaptörvény-ellenesnek nyilvánította és megsemmisítette. Álláspontja szerint az ítélet sértette az Alaptörvény IX. cikke által biztosított véleménynyilvánítási és sajtószabadságot, ahogyan azokat az Alkotmánybíróság korábban, a 28/2014. Abh.-ban értelmezte. Tekintettel arra, hogy ezen hiteles és mindenkire, így az eljáró bíróságokra is kötelező alkotmánybírósági interpretációval szemben a bíróság megszorító módon értelmezte a ,jelenkor eseménye”, illetve a "közérdeklődésre számot tartó esemény” fogalmát, a Fővárosi Bíróság ítélete alaptörvény-ellenes, mert nem a véleménynyilvánítási, illetve a sajtószabadságnak, hanem a közhatalmat képviselő rendőr képmáshoz való jogának biztosított elsőbbséget. ${ }^{36}$

Az Alkotmánybíróság felhívta a figyelmet arra, hogy a 28/2014. Abh.-ban az ütköző jogok közül egyértelműen a sajtószabadság primátusát mondta ki általában a személyhez füződő jogok, így a képmáshoz való jog felett is. A sajtószabadságnak csak akkor kell az emberi méltósághoz való jogból levezethetö, az Alaptörvényben önállóan nem nevesített képmáshoz való joggal szemben meghátrálnia, ha a sajtószabadság teljes körü gyakorlása az emberi személyiség lényegi magját, az ember méltóságát sértené. llyen sérelem hiányában a nem visszaélésszerü, nem önkényes, azaz tárgyilagos és tényszerü, akár a jelenkor eseményeiről, akár a közhatalom gyakorlása szempontjából közérdeklődésre számot tartó ügyröl szóló tudósítás nem korlátozható. Az eljáró bíróságok azon értelmezése, miszerint a régi Ptk. 80. $\S(2)$ bekezdésének az 1/2012. BKMPJE által megállapított és érvelésük szerint a 28/2014. Abh.-val is összhangban álló, abból következő jelentése az lenne, hogy a rendőrök felismerhető ábrázolása csak azon két feltétel együttes fennállása esetén nem önkényes, ha egyrészt az olyan eseményröl történő tudósítás keretében jelenik meg, amely esemény a múltban még nem történt meg, másrészt hogy e tudósítás - a rendőrök ábrázolásával kapcsolatban - jogszerüen kizárólag a rendőrök eljárási szabályszegéséröl szólhat, alaptörvény-ellenes. Ez ugyanis ténylegesen a 28/2014. Abh.-ban korábban lefektetett alkotmányossági szempontokkal ellentétesen korlátozza a sajtószabadságot, illetve az ott kifejtetteknél szükebb körben engedi meg annak érvényesülését. ${ }^{37}$

A véleménynyilvánítási szabadság részét képező, annak egyik legfontosabb megnyilvánulási formáját jelentő sajtószabadság - magának a véleménynyilvánítási szabadságnak a jogához hasonlóan - egyrészt a személyiség kifejezését, másrészt és legföképpen a demokratikus közvélemény kialakítását és fenntartását szolgálja..$^{38}$ Ebből fakadóan korlátozásuk csak különösen indokolt esetben lehetséges; nem visszaélésszerü, nem önkényes joggyakorlás esetén csak akkor, ha azzal az emberi méltóság alapvető joga kerülne szembe. Az Alkotmánybíróság nem állított olyan fel-

\footnotetext{
36 Indokolás [17]-[20].

37 Indokolás [19] és [23].

38 Indokolás [22].
} 
tételt a sajtószabadság védelme és teljes körü érvényesülése (így a szolgálatukat teljesítő és ezáltal a közhatalom gyakorlásában részt vevő rendőrök arcképének felismerhető közzététele) elé, amelyet az első- és a másodfokú bíróság az ítéletében kifejtett. Ha a ,jelenkor eseményének” csak olyan eseményt lehetne elismerni, amely a múltban még nem történt meg, akkor nagyon sok eseményröl - például tüntetésekről - nem tudósíthatna a sajtó a maga teljességében, ami a sajtószabadság jogával nyilvánvalóan ellentétes lenne. Úgyszintén a sajtószabadság részét képező tájékoztatáshoz és tájékozódáshoz való jogból következik az is, hogy a sajtónak joga van a nem jogszerütlen rendőri cselekményekről is tudósítani, illetve a közvéleménynek a rendőri eljárás jogszerủ voltát mint tényt is joga van megismerni, mert enélkül épp a közhatalom-gyakorlás jogszerüsége ellenőrzésének lehetősége veszne el.

Végül általános jelleggel azt is leszögezte az Alkotmánybíróság, hogy bár a rendes bíróságok feladata az alkotmányos szempontok érvényesítése - hiszen az eljárás lefolytatása, a bizonyítékok megállapítása és a jogszabályoknak az ítélet meghozatalához szükséges értelmezése az ő alkotmányos jogállásuk része -, az már az Alkotmánybíróság alkotmányos jogállásának a folyománya, hogy a bíróságok ezen értelmezése Alaptörvénynek való megfelelőségét ellenőrizze, ennek keretében pedig számon kérje a bíróságokon azt is, hogy a jogszabályokat az Alaptörvénnyel összhangban alkalmazzák. E kötelezettség az ilyen autentikus értelmezést tartalmazó alkotmánybírósági határozat közzétételének napjától (vagy az abban foglalt más időponttól) kezdve terheli a bíróságokat, az ilyen határozat ugyanis ezen időponttól fogva hatályosul és mindenki számára kötelező. ${ }^{39} \mathrm{E}$ kötelező erő nem függ attól sem, hogy létezik-e olyan jogegységi határozat, amely az Alkotmánybíróság alkotmányos jogszabály-értelmezésének ellentmond; a bíróságok ebben az esetben is a jogszabályoknak az $A B$ határozatban foglalt alkotmányos értelmét kell hogy figyelembe vegyék. ${ }^{40}$

A 17/2016. (X. 20.) AB határozat ${ }^{41}$ alapjául szolgáló ügyben szintén egy rendör indított személyiségi jogi pert, ez esetben a hvg.hu internetes hírportált is üzemeltető HVG Kiadó Zrt. ellen, mert a médiaszolgáltató a 2012. évi Budapest Pride rendezvényről szóló sajtótudósítás online képgalériájában felismerhető módon tett róla közzé egy képet, miközben a rendezvény biztosítása érdekében látott el szolgálatot az egyik minisztérium épülete elött. A képen ugyan homályosan mások is láthatóak voltak, a fényképezőgép azonban egyértelműen a rendőrre fókuszált, annak

39 Indokolás [13], [16] és [24]-[25].

40 A szakirodalomban ugyanakkor e határozat kapcsán megfogalmazódott az a kritika is, mely szerint az Alkotmánybíróság adós maradt annak bemutatásával, hogy a 28/2014. Abh., illetve a 16/2016. Abh. alapjául szolgáló tényállások és az azokat elbíráló rendes bírói döntések között milyen lényeges eltérések vannak. Így például Papp János Tamás szerint „könnyebb dolga lenne a jövöben a jogalkalmazónak, ha az Alkotmánybíróság indokolásában pontositotta volna, hogy jelen esetben [ti. a 16/2016. Abh. által elbírált alapügyben] miként kell alkalmazni az Alkotmánybiróság által korábban meghatározott elveket". PAPP János Tamás: Az Alkotmánybíróság két újabb határozata a rendvédelmi dolgozók képmásának nyilvánosságáról. Jogesetek Magyarázata, 2016/4, 10.

41 ABH 2016, 1212. E határozathoz szintén Dienes-Oehm Egon és Pokol Béla alkotmánybírák füztek különvéleményt. 
teljes alakját, valamint - bár napszemüvegben, mégis felismerhető módon - arcát is bemutatva. Az ily módon őt egyediesítetten ábrázoló fényképfelvétel közzététele miatt a rendőr azt kérte a bíróságtól, hogy állapítsa meg a képmáshoz füződő személyiségi jogának tartalomszolgáltató általi megsértését, tiltsa el az alperes sajtószervet a további jogsértéstöl (praktikusan kötelezze azt a fényképnek az internetes képgalériájából való eltávolítására), illetve adjon számára megfelelő elégtételt egy magánlevélben foglalt, de általa nyilvánosságra hozható bocsánatkérés formájában.

A Fővárosi Törvényszék helyt adott a felperes keresetének, ${ }^{42}$ és ítéletében megállapította, hogy a rendör nem közszereplö, mivel az akkor már hatályban lévő 1/2012. BKMPJE ezt az értelmezést kizárja. E döntést a másodfokon eljáró Fővárosi Ítélőtábla helybenhagyta. ${ }^{43} \mathrm{Az}$ Ítélőtábla döntésének meghozatalakor már ismerte a 28/2014. Abh.-t, ám mérlegelési jogával élve arra a következtetésre jutott, hogy mivel az AB határozat egyedi ügyben született, az 1/2012. BKMPJE pedig, melynek hatályát az Alkotmánybíróság döntése nem érintette, a bíróságokra kötelező, így továbbra is a polgári jogi normák és a polgári jogi dogmatika, illetve az ezekre épülő bírói gyakorlat szerint kell eljárnia. Ezek alapján pedig a jogsértés megtörtént, a rendőrt ismerősei számára felismerhető módon ábrázoló képfelvétel nyilvánosságra került, az online tartalomszolgáltató pedig nem kérte és nem kapta meg az ábrázolt személy hozzájárulását. Így az Ítélőtábla a közhatalmat gyakorló, de nem közszereplő rendőr kereseti kérelmének helyt adó elsőfokú ítéletet - annak helyes indokaira tekintettel - helybenhagyta.

Az alperes a jogerős döntés ellen felülvizsgálati kérelmet nyújtott be, azt azonban a Kúria elutasította. ${ }^{44} \mathrm{~A}$ Kúria egyetértett a jogerős ítélet indokolásával abban, hogy az egyedi ügyben született $A B$ határozat nem köti a bíróságot, és mivel az sem a régi Ptk. 80. §-át, sem az azt értelmező 1/2012. BKMPJE-t nem semmisítette meg, így azok továbbra is alkalmazhatóak voltak. Kimondta, hogy a 28/2014. Abh. nem vonatkozik azon esetre, amikor a nyilvánosságra hozni kívánt képmás ábrázolása egyediesített, vagyis azon lényegileg egy személy látható.

Az Alkotmánybíróság ebben az ügyben is kimondta ezen értelmezés alaptörvényellenességét, és 17/2016. (X. 20.) AB határozatával mind a Kúria, mind a Fővárosi Ítélőtábla jogerős döntését megsemmisítette. Az Alkotmánybíróság szerint a véleménynyilvánítási és a sajtószabadság mind alanyi jogként, mind a demokratikus akaratképzés eszközeként (az állam objektív intézményvédelmi kötelezettségeként, azaz a szubjektív jog alapjául szolgáló érték, illetve társadalmi érdek önálló védelmére irányuló kötelezettségként) kiemelt védelmet élvez, így az azt korlátozó jogszabályokat megszorítóan kell értelmezni. A rendőr, mint a közhatalom gyakorlója, a sajtószabadsággal szemben csak akkor hivatkozhat személyiségi jogaira, ha a sajtószabadság gyakorlása önkényes, visszaélésszerü, továbbá ha a közfeladatának ellátásával összefüggésben a rendőrt ábrázoló képfelvétel a rendőr emberi méltósághoz való jogának a sérelmét okozná. A rendőr, mint a közhatalom letéteményese, mind a jelenkor eseményeiről szóló, mind a közhatalom gyakorlása szem-

\footnotetext{
42 A Fővárosi Törvényszék 65.P.23.669/2012./7. számú ítélete, 2013. május 23.

43 A Fővárosi Ítélőtábla 2.Pf.20.186/2014/4. számú ítélete, 2014. október 30.

44 A Kúria Pfv.IV.20.238/2015/4. számú ítélete, 2015. április 15.
} 
pontjából egyébként közérdeklődésre számot tartó esemény kapcsán felismerhető módon megjeleníthető, akkor is, ha nem közszereplő, és akkor is, ha a felvétel őt közhatalmi feladatai ellátása közben egyediesített módon ábrázolja. ${ }^{45}$ A 28/2014. Abh. ezen alkotmányos tartalmát a bíróságok nem írhatják felül, attól nem térhetnek el; a jogalkalmazás során kötve vannak a normák alkotmányos értelmét meghatározó Alaptörvényhez és annak egyedül hiteles, Alkotmánybíróság általi értelmezéséhez, ${ }^{46}$ mégpedig az Alkotmánybíróság határozata közzétételét követő (vagy az e határozatban megállapított későbbi) időponttól kezdve. ${ }^{47}$

Összességében az Alkotmánybíróság a rendőrképmásos ügyek alkotmányos megítélése során jogalakító (de nem jogalkotó) tevékenységet fejtett ki azzal, hogy a Ptk. 2:44. §-ának (a közéleti szereplő személyiségi jogának védelméről szóló szakaszának) értelmezése során az addigi, személyiségvédelemmel, azon belül is a Ptk. 2:43. §g) pontjában található képmásvédelemmel kapcsolatos polgári jogi dogmatikából és bírói gyakorlatból következő szempontokon túli, további követelményt fogalmazott meg a bíróságok számára. Eszerint az a rendelkezés, hogy „a közügyek szabad vitatását biztosító alapjogok gyakorlása a közéleti szereplő személyiségi jogainak védelmét szükséges és arányos mértékben, az emberi méltóság sérelme nélkül korlátozhatja", immár nemcsak azt a kötelezettséget foglalja magában, hogy a tömegfelvételen látható személy, illetve a nyilvános közéleti szereplést vállaló személy köteles türni, hogy képmását engedélye nélkül is nyilvánosságra hozzák, hanem azt is, hogy a közhatalom gyakorlójaként eljáró személyek is kötelesek türni, hogy mind a jelenkor eseményeiről szóló, mind a közhatalom gyakorlása szempontjából egyébként közérdeklődésre számot tartó eseményekről történő tudósítások során - akár egyediesített módon is - nyilvánosan ábrázolhatóak legyenek.

Mivel az Alkotmánybíróság e tanulmányban vizsgált határozatai általában véve a közhatalom gyakorlóiról, letéteményeseiröl beszélnek, ezért e határozatok alkotmányos tartalma túlmutat a rendőrök - e minőségükben való eljárásuk kapcsán történő - felismerhető bemutatásának a sajtó számára biztosított lehetőségén. Bár e határozatok mind rendőrökröl szóltak, azok megfogalmazásából az következik, hogy fő szabályként a közhatalom gyakorlói általában kötelesek képmáshoz füződő személyiségi joguk korlátozását türni, azért, hogy a véleménynyilvánítási szabadság

45 Indokolás [28].

46 Indokolás [29].

47 Indokolás [25]. A rendes bíróságok vonakodását az Alkotmánybíróság által megfogalmazott, jelen írásban bemutatott alapjogi követelmények érvényesítésére a rendőrképmásos ügyekben alighanem megszüntetné, ha maga a jogalkotó deklarálná, hogy ilyen esetekben a rendőrök képmáshoz való joga háttérbe szorul a sajtószabadsághoz képest. Ez akkor is megoldást jelentene a jelenleg fennálló problémára, ha valójában megkerülné azt, mivel az nem lenne szükséges, hogy e jogszabályi módosítás alapjogi, illetve alkotmányossági szempontok alapján szülessen meg. Így pl. Boronkay Miklós szerint „lehetőség lenne az Infotv. olyan irányú módosítására, amely kimondaná: a közhatalmat gyakorló személy képmása is közérdekből nyilvános adat”. [Boronkay Miklós: A képmáshoz és a hangfelvételhez füződő jog. In: Csehi Zoltán - Koltay András - Navratyil Zoltán (szerk.): A személyiség és a média a polgári és a büntetőjogban. CompLex, Budapest, 2014,22 .] Más kérdés, hogy ez a konkrét megoldás egyrészt a „közhatalmat gyakorló személy” fogalmának meghatározatlansága miatt újabb, például a köztisztviselőkkel, kormánytisztviselőkkel, katonákkal stb. kapcsolatos problémákat vetne fel, másrészt - a felmerülő problémát valóban megkerülve - elodázná az Alkotmánybíróság és a rendes bíróságok közti hatásköri viszonyok tisztázását. 
részét képező sajtószabadság érvényesülhessen. Ennek következtében a jövőben mindazok, akik e kategóriába tartoznak, közhatalmi jellegü tevékenységük közben felismerhető módon bemutathatóak lesznek; képmáshoz való személyiségi joguk tehát e tevékenységük során háttérbe kell hogy szoruljon a sajtószabadság érvényesülése érdekében. Nyilvánvalóan a közhatalom gyakorlója a büntetés-végrehajtási felügyelő, a közterület-felügyelő, erdőőr, mezőőr stb.; véleményes azonban, hogy egy minisztériumban dolgozó kormánytisztviselő, egy önkormányzatnál dolgozó köztisztviselő stb. szintén a közhatalom (képmáshoz füződő személyiségi jogának háttérbe szorítására köteles) gyakorlója-e.

Ugyanakkor meg kell említeni ezen alkotmányos szempont következetes alkalmazásának legföbb veszélyét is. Ha ugyanis a rendőr (büntetés-végrehajtási felügyelő, közterület-felügyelő stb.) felismerhető módon látható, azzal őt a jogrendszer annak a veszélynek teszi ki, hogy mégoly jogszerủ intézkedése miatt is testi épsége, szabadsága, szélsőséges esetben akár az élete is veszélybe kerülhet, mivel az intézkedéssel érintett (például letartóztatott) személy hozzátartozói, barátai, bűntársai rajta bosszút állhatnak. Emiatt a jövőben, ilyen jellegú esetek felmerülésekor alighanem szükséges lesz megfogalmazni egy olyan distinkciót, melynek értelmében a politikai vagy más közéleti tevékenységgel összefüggésben álló, közhatalmat gyakorló személyekröl történő, sajtó általi képmásközzététel alkotmányosan továbbra is védett marad, de más alkotmányos jogok, célok és értékek védelme érdekében. Például ilyen indokból a bünszervezet vezetőjeként elkövetett súlyos bűncselekmények miatt megvádolt személyt a bírósági tárgyalóterembe kísérő fegyőr arcmását továbbra is ki lehetne (illetve kellene) majd takarni - ahogyan az egyébként ma is történik a sajtó gyakorlatában. Nyilvánvalóan nem mindegy ugyanis, hogy a közhatalmat gyakorló személy ezt egy, a demokratikus akaratképzéshez közvetlenül kapcsolódó eseményen (például egy tüntetésen), illetve azzal összefüggésben teszi-e, vagy pedig súlyos büncselekmények elkövetőinek felelősségre vonása érdekében (vagy más hasonló okból).

\section{Konklúzió}

Az Alkotmánybíróság immár több határozatból kirajzolódó újabb gyakorlata szerint a gyülekezési jog gyakorlását megvalósító demonstrációkon biztosítási, irányítási feladatokat végző rendőr nem magánszemélyként, hanem a közhatalom képviseletében jár el, így az emberi méltósághoz való joga részét képező képmáshoz füződő személyiségi jogának védelme szükebb körü, mint más természetes személyek esetében. Az ilyen demonstrációk mindig a jelenkor történésének minősülnek, amely történésről - a sajtószabadság részét képező, a közéleti eseményekről történő szabad tájékoztatás jogából fakadóan - az esemény teljessége, annak minden részlete a nyilvánosság számára közvetíthető, beleértve a demonstráción szolgálatot teljesítő rendörök arcképének felismerhetö bemutatását is, amennyiben annak rögzítésére ezen esemény kapcsán került sor, és az sem az emberi személyiség lényegi magvát, az emberi méltósághoz való jogot nem sérti, sem visszaélésszerünek nem tekinthető. Ugyanez igaz a rendőr minden olyan tevékenységére is, amely 
a közhatalom gyakorlása szempontjából közérdeklődésre tart számot, azaz amely esetben a rendör mint a közhatalom gyakorlója - és nem mint magánszemély - jár el, függetlenül attól, hogy dokumentált tevékenysége jogellenes vagy jogszerü-e.

Emellett az Alkotmánybíróság a konkrét jogértelmezési problémán túlmenő, az egész jogrendszer működése szempontjából alapvető jelentőségú kérdésben is lándzsát tört amellett, hogy az Alaptörvény egyedüli hiteles értelmezésének joga ezt a testületet illeti meg, mely értelmezés konkrét esetekben való alkalmazása mindenki számára - tehát a konkrét ügyekben eljáró bíróságok, így a Kúria számára is - kötelező. A bíróság mint az igazságszolgáltatás szerve ugyan független, így döntését csak a jogszabályok kötik, ezek értelmezésekor azonban figyelemmel kell lennie az Alaptörvény rendelkezéseire is, mivel a bíróságok a jogszabályokat az Alaptörvénynyel összhangban kell hogy értelmezzék. Az Alaptörvény hiteles, mindenkire kötelező alkotmányos értelmét az erre irányuló hatáskörrel felruházott, az Alaptörvény védelmét ellátó szerv, az Alkotmánybíróság határozza meg. A rendes bíróságoknak tehát eljárásuk során a jogszabályok alkotmányos értelmét ezen értelmezés alapulvételével kell megállapítaniuk, attól nem térhetnek el: az alkotmányos értelmet se nem módosíthatják, se nem szűkíthetik, se nem szelektálhatnak belőle.

\section{Abstract}

The Constitutional Court of Hungary, proceeding in its new competence regarding the "real" constitutional complaint obtained from 1 January 2012, is allowed to adjudicate the motions initiated against concrete judicial decisions which are deemed to be contrary to the Fundamental Law of Hungary. Within this procedure the Constitutional Court places the protection of the freedom of expression and freedom of the press above the protection of personality rights. The Court consistently annuls judicial decisions that declare infringement of personality rights on grounds that a press agency published recognizable facial likeness of police officers being on duty during demonstrations. The present paper analyses the course during which the Constitutional Court does enforce the constitutional requirements elaborated in its former practice and, thereby, repeals the ordinary courts' decisions if those favour the personality rights of police officers over the freedom of the press. 